Abstracta Iranica Iranica

Revue bibliographique pour le domaine irano-aryen

Volume 32-33 | 2013

Comptes rendus des publications de 2009-2010

\title{
Doris Behrens-Abouseif. The Jalayirid connection in Mamluk metalware
}

Nourane Ben Azzouna

\section{OpenEdition}

1 Journals

Édition électronique

URL : http://journals.openedition.org/abstractairanica/40790

DOI : 10.4000/abstractairanica.40790

ISSN : 1961-960X

\section{Éditeur :}

CNRS (UMR 7528 Mondes iraniens et indiens), Éditions de l'IFRI

\section{Édition imprimée}

Date de publication : 1 décembre 2013

ISSN : 0240-8910

\section{Référence électronique}

Nourane Ben Azzouna, "Doris Behrens-Abouseif. The Jalayirid connection in Mamluk metalware », Abstracta Iranica [En ligne], Volume 32-33 | 2013, document 302, mis en ligne le 01 juillet 2016,

consulté le 26 septembre 2020. URL : http://journals.openedition.org/abstractairanica/40790 ; DOI : https://doi.org/10.4000/abstractairanica.40790

Ce document a été généré automatiquement le 26 septembre 2020.

Tous droits réservés 


\title{
Doris Behrens-Abouseif. The Jalayirid connection in Mamluk metalware
}

\author{
Nourane Ben Azzouna
}

\section{RÉFÉRENCE}

Doris Behrens-Abouseif. « The Jalayirid connection in Mamluk metalware ». Muqarnas, 26, 2009, p. 149-159.

1 Cet article se penche sur la question du lieu de production d'un grand bassin en cuivre à décor gravé inscrit au nom du sultan jalayiride Shaykh Uways (1356-1374), actuellement au Musée d'Art Islamique à Téhéran. Ce bassin a jusqu'à présent été attribué au nord de l'Iraq ou au nord-ouest de l'Iran jalayiride, mais l'A. de l'article propose une nouvelle attribution : à la Syrie mamelouke. Après une introduction sur l'histoire de l'art du métal mamelouk, divisée en deux grandes périodes : le règne des Mamelouks Bahrites (deuxième moitié du XIII ${ }^{e}$-XIV ${ }^{e}$ s.) puis, après un demi-siècle de déclin, la fin de la période mamelouke (deuxième moitié du XVe-début du XVI ${ }^{e} \mathrm{~s}$.), l'auteur présente une description détaillée du décor très élaboré et raffiné du bassin jalayiride. Ensuite, elle admet n'avoir identifié aucun précurseur direct à ce bassin, mais propose des rapprochements avec plusieurs groupes de métaux mamelouks. Certains de ces rapprochements, en particulier celui avec une production encore peu connue de petits bassins et de bols en cuivre à décor gravé dont la provenance syroégyptienne et la datation $\mathrm{du}^{\mathrm{XIV}}{ }^{\mathrm{e}} \mathrm{s}$. semblent assurées, sont particulièrement intéressants. Il est cependant regrettable que l'A. ne donne pas suffisamment d'indications sur l'inscription du bassin de Shaykh Uways et ne développe pas la comparaison avec une autre série de bols qui sont, eux, ornés de vers persans et signés par des artistes d'origines iraniennes diverses, depuis le Horōāān jusqu'au Fārs 
contemporain. Pour ces raisons, l'hypothèse de la provenance mamelouke du bassin de Shaykh Uways nous semble encore discutable.

\section{AUTEURS}

\section{NOURANE BEN AZZOUNA}

Agence France Muséums-Louvre, Abu Dhabi 